University of Nebraska - Lincoln

DigitalCommons@University of Nebraska - Lincoln

Faculty Publications: Department of Entomology

Entomology, Department of

2007

\title{
Immersion Tolerance in Rangeland Grasshoppers (Orthoptera: Acrididae)
}

Mathew L. Brust

University of Nebraska-Lincoln, mbrust@csc.edu

W. W. Hoback

University of Nebraska at Kearney, whoback@okstate.edu

Robert J. Wright

University of Nebraska-Lincoln, rwright2@unl.edu

Follow this and additional works at: https://digitalcommons.unl.edu/entomologyfacpub

Part of the Entomology Commons

Brust, Mathew L.; Hoback, W. W.; and Wright, Robert J., "Immersion Tolerance in Rangeland Grasshoppers (Orthoptera: Acrididae)" (2007). Faculty Publications: Department of Entomology. 154.

https://digitalcommons.unl.edu/entomologyfacpub/154

This Article is brought to you for free and open access by the Entomology, Department of at DigitalCommons@University of Nebraska - Lincoln. It has been accepted for inclusion in Faculty Publications: Department of Entomology by an authorized administrator of DigitalCommons@University of Nebraska - Lincoln. 


\title{
Immersion tolerance in rangeland grasshoppers (Orthoptera: Acrididae)
}

Accepted July 26, 2007

\author{
Mathew L. Brust, W.W. Hoback And R.J. Wright
}

(MLB, RJW) Department of Entomology, Plant Industry Building, University of Nebraska-Lincoln, 202 Plant Industry Building, Lincoln, NE 68583. Email: mbrust1 @bigred.unl.edu; rwright@UNLNOTES.UNL.EDU

(WWH) Department of Biology, Bruner Hall of Science, University of Nebraska at Kearney, 905 W. 25 th Street, Kearney, Nebraska 68849. Email: hobackww@unk.edu

\begin{abstract}
Population fluctuations of short-horned grasshoppers have been linked to the interactions of numerous factors including precipitation, temperature, vegetative growth, latitude, and timing of rainfall events. In some areas, grasshopper populations decline with increased moisture, potentially as a result of direct mortality from raindrops, or from indirect factors including the increase of fungal pathogens. Grasshoppers may also become submerged by flooding events and suffer mortality from drowning. However grasshopper survival of immersion has not been quantified in controlled experiments. We tested nymph and adult survival of immersion of seven species of rangeland grasshoppers. Under laboratory conditions, the $\mathrm{LT}_{50}$ of adult grasshoppers ranged between 7.5 and $21 \mathrm{~h}$, while nymphs had an $\mathrm{LT}_{50}$ of between 3 and $13 \mathrm{~h}$. Survival times indicate that mortality associated with seasonal rainfall is rarely caused by immersion. The significant resistance to hypoxia by these grasshoppers is not strongly correlated with habitat association and may instead be correlated with life history traits associated with overwintering.
\end{abstract}

\section{Key words}

grasshopper, precipitation, drowning, hypoxia

\section{Introduction}

The relationship between short-horned grasshopper(Orthoptera: Acrididae) numbers and precipitation has been repeatedly investigated in an attempt to predict grasshopper outbreaks in rangelands. Various authors have reported different relationships, which may be related to predominant species, as well as small-scale and largescale geographic features. In some areas lower than normal rainfall appears to limit grasshopper numbers and species diversity. Gage and Mukerji (1977) found many correlations between dry weather and high grasshopper numbers. Parker (1933) and Edwards (1960) found that outbreaks in Saskatchewan were preceded by two to four years of below-normal rainfall in May and June or above-normal temperatures from July to September. Smith (1954) found that outbreaks in Kansas were preceded by two years of below-normal rainfall. Skinner and Child (2000) also reported negative correlations between precipitation and grasshopper numbers in Colorado. The reasons for reductions in grasshopper numbers associated with increased precipitation are currently unknown, but are potentially the result of direct mortality of early instars from raindrop impacts, increases in fungal pathogens, or drowning.

Pickford (1966) speculated that heavy rains resulting in flooding, kill nymphs by drowning. However, Parker (1930) found that nymphs of Camnula pellucida Scudder survived prolonged immersion (up to $19 \mathrm{~h}$ at $22^{\circ} \mathrm{C}$ ) and that survival time was negatively correlated with temperature. Parker's experiment was not well controlled as the water in this study was not rendered hypoxic, and the instars tested were not reported. Because water tends to puddle after rainstorms and because standing water rapidly becomes hypoxic (Baumgärtl et al. 1994), tests of immersion tolerance should be conducted with hypoxic water to quantify the likelihood of drowning for individuals caught in floods. At present, the only example of controlled hypoxia exposure in grasshoppers is by Hochachka et al. (1993), who found that Schistocerca gregaria (Forskal) adults survived $8 \mathrm{~h}$ of hypoxia exposure (nitrogen atmosphere).

Our study quantifies immersion tolerance in hypoxic water in a variety of grasshopper species, in both adult and nymphal stages to document the potential of flooding events to limit grasshopper populations directly. Adults of seven species and nymphs of four species were tested for hypoxia tolerance. These species were chosen because they encompass a variety of habitats, ranging from dry rangeland to river edge areas. We hypothesized that species occurring in areas near water would be more tolerant of immersion and subsequent hypoxia exposure.

\section{Methods}

Hypoxia tolerance was tested on the following species: Ageneotettix deorum (Scudder), Arphia xanthoptera (Burmeister), Chortophaga viridifasciata (DeGeer), Melanoplus confusus Scudder, Melanoplus femurrubrum (DeGeer), Pardalophora haldemani (Scudder), and Trimerotropis maritima (Harris). The location and date of collection of specimens, as well as the number of each life stage tested, including controls, are shown in Table 1. Nymphs used in this study were all second and third instars, with an approximately equal mix of each. All grasshoppers were maintained on fresh grass (mostly Bromus inermis Leyss) until experiments were conducted; they were tested within two days of capture.

Exposure to hypoxic water followed methods of Hoback et al. (1998). Spring water was bubbled with nitrogen gas for approximately 5 min per L to render it severely hypoxic (dissolved oxygen < $0.3 \mathrm{ppm}$ ). Individual grasshoppers were placed in a $15-\mathrm{ml}$ screwcap glass vial (or $30 \mathrm{ml}$ for large females) to which the deoxygenated water was added until full. In nearly all cases a piece of tissue was needed to keep individual grasshoppers from reaching the surface where they might contact small air bubbles. Vials were then sealed and gently tapped to remove any air bubbles adhering to the grasshoppers, the sides of the vial, or the piece of tissue. The vials were 


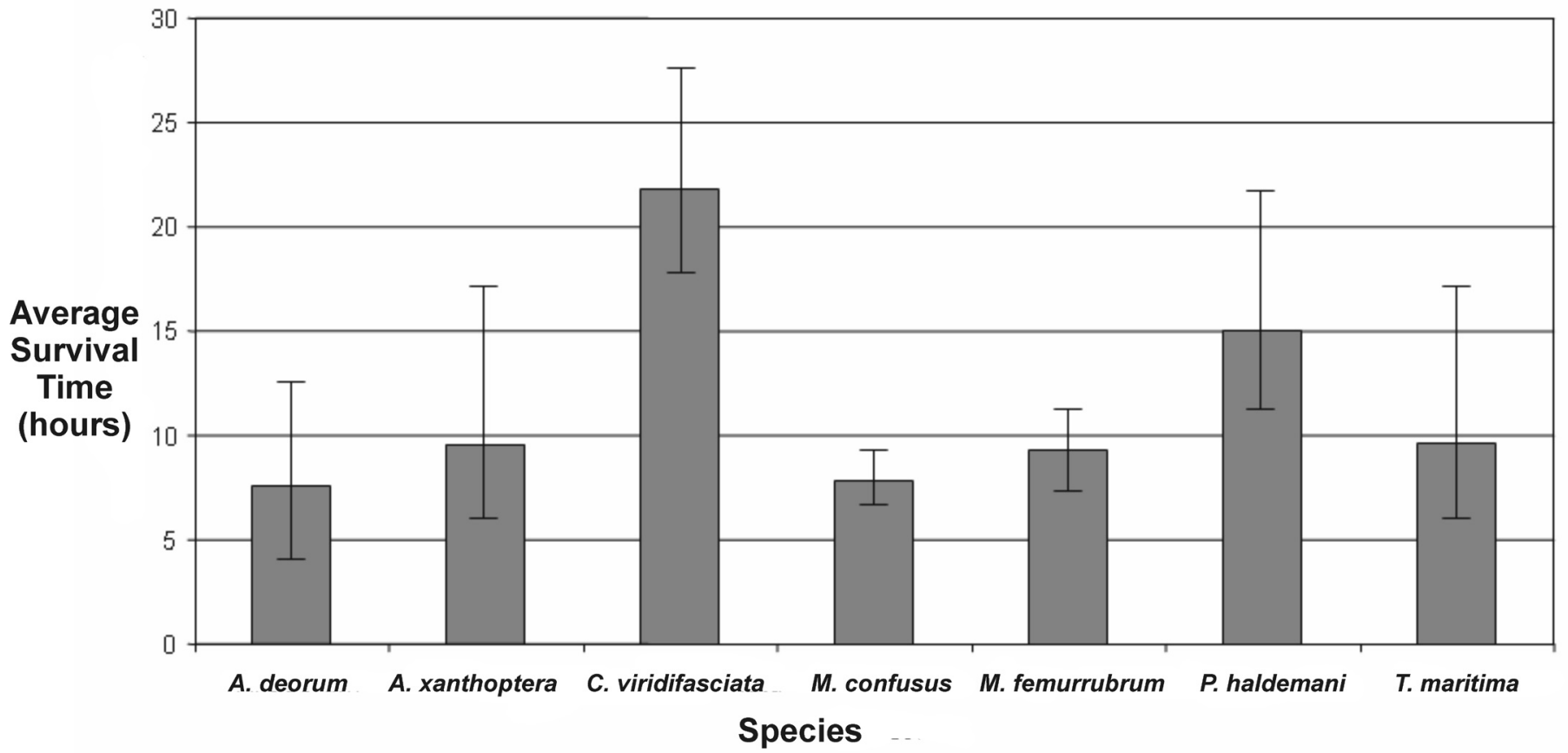

Fig. 1. Average survival time of adult grasshoppers. Error bars represent 95\% confidence interval limits. On the $\mathrm{x}$-axis are the species tested; the y-axis represents the average survival $\left(\mathrm{LT}_{50}\right)$ time under hypoxic conditions.

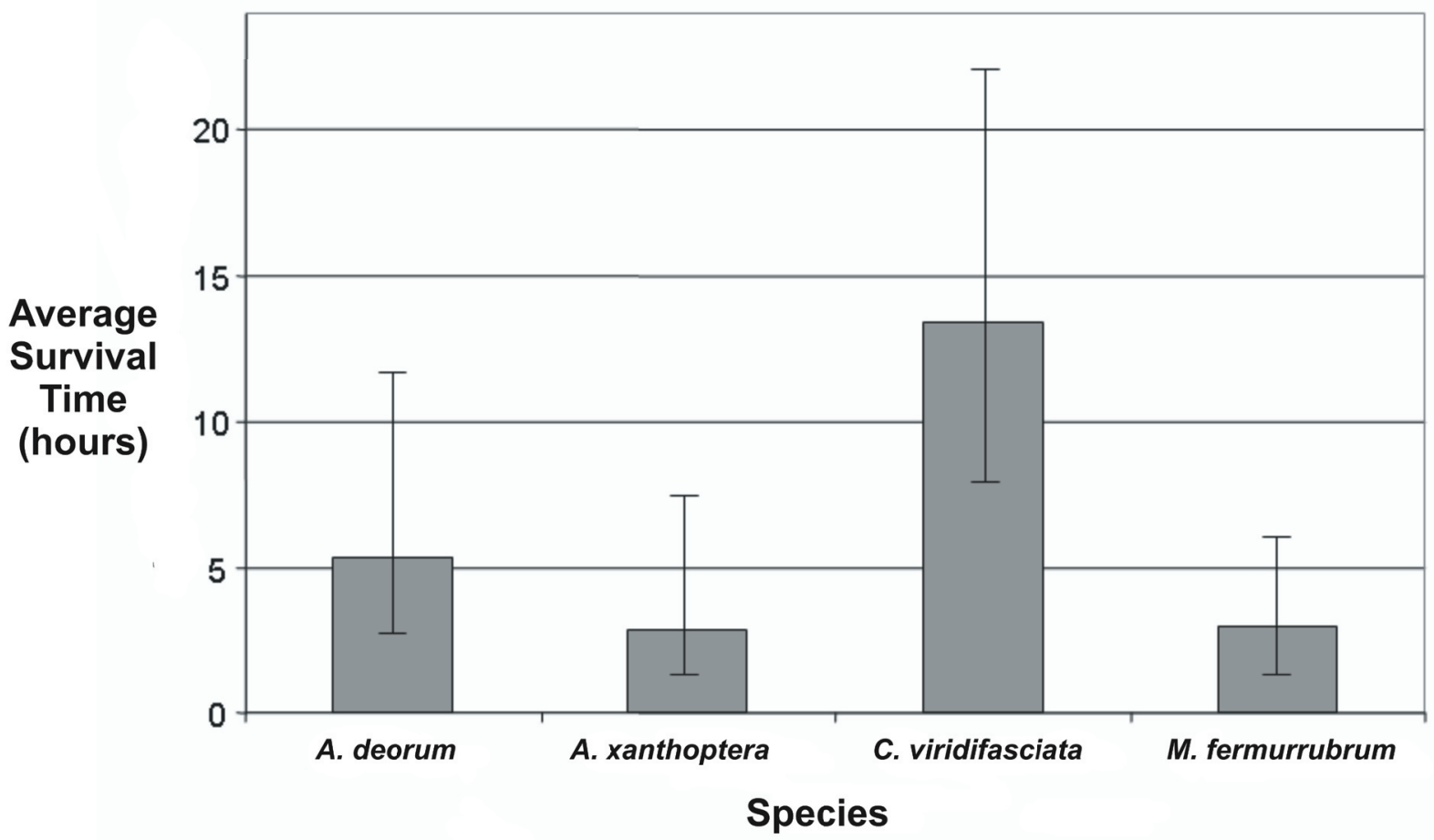

Fig. 2. Average survival time of nymphal grasshoppers. Error bars represent $95 \%$ confidence interval limits. On the x-axis are the species tested; the y-axis represents the average survival $\left(\mathrm{LT}_{50}\right)$ time under hypoxic conditions. 
Table 1. Synopsis of species, life stage, total number of grasshoppers used in study, number per trial, number per control, collection location, and collection date. Collection site numbers: 1 = Nebraska, Buffalo County, 2 mi. SE of Amherst; $2=$ Nebraska, Keith County, 10 mi. N of Ogallala; 3 = Nebraska, Lancaster County, Lincoln; 4 = Nebraska, Dawson County, 3 mi. NW of Sumner; 5 = Nebraska, Dawson County, 6 mi. N of Overton; 6 = Nebraska, Dawson County, 3 mi. S of Lexington.

\begin{tabular}{lcccccc}
\hline \multicolumn{1}{c}{ Species } & Stage & $\begin{array}{c}\text { Total } \\
\text { number }\end{array}$ & $\begin{array}{c}\text { number per } \\
\text { pull }\end{array}$ & $\begin{array}{c}\text { number } \\
\text { control }\end{array}$ & $\begin{array}{c}\text { Collection } \\
\text { site no. }\end{array}$ & $\begin{array}{c}\text { Collection Date } \\
\text { 2006 }\end{array}$ \\
\hline A. deorum & adult & 45 & 5 & 5 & 1 & June 3 \\
A. deorum & nymph & 18 & 3 & 3 & 2 & July 7 \\
A. xanthoptera & adult & 27 & 3 & 3 & 3 & August 16 \\
A. xanthoptera & nymph & 21 & 3 & 3 & 3 & June 28 \\
C. viridifasciata & adult & 54 & $6(3 \mathrm{~m}, 3 \mathrm{f})$ & $6(3 \mathrm{~m}, 3 \mathrm{f})$ & 3 & April 14 \\
C. viridifasciata & nymph & 27 & 3 & 3 & 3 & August 31 \\
M. confusus & adult & 42 & $6(3 \mathrm{~m}, 3 \mathrm{f})$ & $6(3 \mathrm{~m}, 3 \mathrm{f})$ & 4 & June 4 \\
M. femurrubrum & adult & 42 & $6(3 \mathrm{~m}, 3 \mathrm{f})$ & $6(3 \mathrm{~m}, 3 \mathrm{f})$ & 3 & August 16 \\
M. femurrubrum & nymph & 35 & 5 & 5 & 3 & July 1 \\
P. haldemani & adult & 42 & $6(3 \mathrm{~m}, 3 \mathrm{f})$ & $6(3 \mathrm{~m}, 3 \mathrm{f})$ & 5 & June 4 \\
T. maritima & adult & 27 & 3 & 3 & 6 & August 18 \\
\hline
\end{tabular}

then placed in an unlighted environmental chamber at $20^{\circ} \mathrm{C}$.

For controls individual grasshoppers were placed in glass vials as above together with a damp paper towel. The vials were closed with a loosely fitted cap and the grasshoppers ( $\mathrm{N}=3$ per species) were placed into the environmental chamber at the same time as experimental grasshoppers. Controls were checked during each trial. During the 36-h time course of the experiments no control grasshoppers died.

Subsets of individual grasshoppers were then removed at 2, 4, 6, $8,10,12,24$, and in some cases $36 \mathrm{~h}$, and allowed to recover. The grasshoppers were placed individually in small plastic containers and returned to the environmental chamber.

Grasshoppers unable to walk after $24 \mathrm{~h}$ were recorded as dead. Survivorship data were analyzed using Toxstat 3.4 (Western Ecosystems Technology, Inc., Cheyenne, Wyoming), which calculates time to $50 \%$ mortality $\left(\mathrm{LT}_{50}\right.$ ) and $95 \%$ confidence intervals by probit anlaysis. The $\mathrm{LT}_{50}$ is synonymous with average survival time. Significant differences in survivorship were determined by nonoverlapping 95\% confidence intervals (Hoback et al. 1998).

\section{Results}

The average survival time of adult $C$. viridifasciata was the highest $\left(\mathrm{LT}_{50}=21.86 \mathrm{~h}\right)$ and was different from all other species except $P$. haldemani (based on 95\% confidence intervals) (Fig. 1). The average survival time of $P$. haldemani was the second highest, but overlapped with all species except $M$. confusus. All species that overwinter in the egg stage had average survival times between 7 and $10 \mathrm{~h}$. All adult species tested had average survival times in hypoxic water exceeding $7 \mathrm{~h}$.

Compared to adults, grasshopper nymphs had reduced survival times. All nymphal species tested survived immersion in hypoxic water for more than $2 \mathrm{~h}$. Among the nymphs, C. viridifasciata had the highest average survival time $\left(\mathrm{LT}_{50}=13.38 \mathrm{~h}\right)$ and differed from all others tested except $A$. deorum (Fig. 2). The average survival time of $A$. deorum nymphs did not differ from any other species tested, and all species except $C$. viridifasciata had average survival times of less than $6 \mathrm{~h}$.

\section{Discussion}

The results of this study show that adult grasshoppers are capable of surviving more than $7 \mathrm{~h}$ in severely hypoxic floodwater. Survival time decreased to 3 to $8 \mathrm{~h}$ in the nymphal stage. Thus it appears that heavy rains resulting in flooding events seldom have substantial impacts on most species of rangeland grasshopper, contrary to the suggestion of Pickford (1966). The life stage of the grasshoppers affected survival, with adults being more tolerant than nymphs, suggesting that the earliest instars may be more susceptible to drowning. It seems likely that body mass correlates with hypoxia resistance as a result of larger insects trapping more air in their trachea and having more carbohydrate reserves to use during anaerobic metabolism (Hochachka et al. 1993, Hoback \& Stanley 2001). If true for these species, immersion episodes of 1 to $2 \mathrm{~h}$ are likely to be fatal for first instars of most species, based on their body masses. However, body mass alone does not appear to explain differences in survival times among all species tested.

Nymphal C. viridifasciata survived hypoxia longer than any other species, and the 95\% confidence interval overlapped only with that of $A$. deorum. The apparent hardiness of nymphs of this species might be a result of its life cycle. C. viridifasciata overwinters in the nymphal stage mostly in the fourth and fifth instar (Pfadt 2002). As this species is mostly found in moist areas such as stream floodplains, it is thus likely to be exposed to periods of flooding during spring snowmelt and cold spring rainstorms.

Adults of species that overwinter as nymphs (C. viridifasciata and $P$. haldemani) also survived hypoxia longer than other species, although only C. viridifasciata differed from all tested species that overwinter as eggs based on nonoverlapping confidence intervals. Because the adults are active earlier in the season when soils are often more saturated, hypoxia survival may be more important for adults of C. viridifasciata than other species.

Hypoxia tolerance may be important to all acridid species that overwinter in the nymphal stage. Hypoxia results when insects are encased in snow and ice (Hoback \& Stanley 2001). Extreme tolerance to hypoxia under cold conditions has been shown in carabids (Conradi-Larsen \& Sømme 1973) and an alpine chrysomelid (Meidell 1983). Moreover, Leinaas and Sømme (1984) found differences in hypoxia tolerance between two alpine collembolans, and the differ- 
ences appear to correspond with habitat differences and likelihood of being encased in ice (Hoback \& Stanley 2001).

This study shows that rangeland grasshoppers are, for the most part, tolerant of brief periods of immersion, as suggested by Parker (1930). Although numerous authors suggest that heavy precipitation has a negative effect on grasshopper populations, direct deaths as a result of drowning are likely uncommon. First instars, being small and vulnerable, may be killed directly by large raindrops, but even they can probably survive one to two hours of immersion. Fungal pathogens, which may increase during moist conditions, are probably the most important mortality factor associated with precipitation which can negatively affect grasshopper populations.

\section{Acknowledgements}

We owe special thanks to Jennifer Johnson and Heather Tracy for their assistance in this study. We also wish to thank Steve Johnson at USDA-APHIS for allowing us access to information useful to this study. This is manuscript \# 1279 for the Department of Entomology, University of Nebraska. Funding was provided by the University of Nebraska at Kearney Research Services Council.

\section{References}

Baumgärtl H., Kritzler K., Zimelka W., Zinkler D. 1994. Local $\mathrm{PO}_{2}$ measurements in the environment of submerged soil microarthropods. Acta Oecologia 15: 781-789.

Conradi-Larsen E.M., Sømme L. 1973. Anaerobiosis in the overwintering beetle Pelophila borealis. Nature 245: 388-390.

Edwards R.L. 1960. Relationship between grasshopper abundance and weather conditions in Saskatchewan, 1930-1958. Canadian Entomologist 92: 619-624.

Gage S.H., Mukerji M.K. 1977. A perspective of grasshopper population distribution in Saskatchewan and interrelationship with weather. Environmental Entomology 6: 469-479.

Greenbank D.O. 1956. The role of climate and dispersal in the initiation of outbreaks of the spruce budworm in New Brunswick. 1. The role of climate. Canadian Journal of Zoology 34: 453-476.

Hoback W.W., Stanley D.W., Higley L.G., Barnhart C.M. 1998. Survival of immersion and anoxia by larval tiger beetles, Cicindela togata. American Midland Naturalist 140: 27-33.

Hoback W.W., Stanley D.W. 2001. Insects in hypoxia. Journal of Insect Physiology 47: 533-542.

Hochachka P.W., Nener J.C., Hoar J., Saurez R.K., Hand S. C. 1993. Disconnecting metabolism from adenylate control during extreme oxygen limitation. Canadian Journal of Zoology 71: 1267-1270.

Leinaas H.P., Sømme L. 1984. Adaptations in Xenylla maritima and Anurophorus laricis (Collembola) to lichen habitats on alpine rocks. Oikos 43: 197-206.

Meidell E.M. 1983. Diapause, aerobic and anaerobic metabolism in alpine, adult Melasoma collaris (Coleoptera). Oikos 41: 239-244.

Nerney N.J., Hamilton A.G. 1969. Effects of rainfall on range forage and populations of grasshoppers, San Carlos Apache Indian Reservation, Arizona. Journal of Economic Entomology 62: 329-333.

Parker, J. R. 1930. Some effects of temperature and moisture upon Melanoplus mexicanus mexicanus Saussure and Camnula pellucida Scudder (Orthoptera). Montana Agriculture Experiment Station Bulletin, 223. $132 \mathrm{pp}$.

Parker J.R. 1933. Factors largely responsible for years of grasshopper abundance. Proceedings of the World's Grain Exhibition Conference, Canada 2: 472-473.

Pfadt R.E. 2002. A Field Guide To Common Western Grasshoppers. 3rd edition. Wyoming Agricultural Experiment Station, Bulletin 912. 288 pp.
Pickford R. 1966. The influence of the date of oviposition and climatic conditions on hatching of Camnula pellucida (Scudder) (Orthoptera: Acrididae). Canadian Entomologist 98: 1145-1159.

Skinner K.M., Child R.D. 2000. Multivariate analysis of the factors influencing changes in Colorado grasshopper abundances. Journal of Orthoptera Research 9: 103-109.

Smith R.C. 1954. An analysis of 100 years of grasshopper population in Kansas (1854 to 1954). Transactions of the Kansas Academy of Science 57: $397-433$ 